КРИМІНАЛЬНЕ ПРАВО ТА КРИМІНОЛОГІЯ;

КРИМІНАЛЬНО-ВИКОНАВЧЕ ПРАВО

УДК 343.431

DOI https://doi.org/10.32844/2618-1258.2019.5-1.37

АНДРУШКО А.В.

\title{
СПЕЦІАЛЬНО-КРИМІНОЛОГІЧНІ ЗАХОДИ ЗАПОБІГАННЯ ТОРГІВЛІ ЛЮДЬМИ
}

У статті проаналізовано спеціально-кримінологічні заходи запобігання торгівлі людьми. Вказані заходи класифіковано на інформаційно-аналітичні (систематичний збір та аналіз інформації про стан і тенденції розглядуваних злочинів), просвітницькі (інформування населення про небезпечні ситуації, пов'язані з ризиком опинитися у ситуації торгівлі людьми, акцентування на конкретних рекомендаціях про те, як не стати жертвою даного злочину, просвітницька діяльність серед населення, спрямована на зміну ставлення до жертв торгівлі людьми у суспільстві, тощо), правові (удосконалення Закону України «Про протидію торгівлі людьми», кримінального законодавства, спрямованого на протидію таким посяганням, а також практики його застосування, подолання надмірної м'якості судової репресії при призначенні покарання за цей злочин), організаційно-управлінські (підвищення професійного рівня працівників правоохоронних органів, вдосконалення взаємодії правоохоронних органів та інститутів громадянського суспільства, державний захист і реабілітація жертв торгівлі людьми тощо), політичні (активізація діяльності, спрямованої на укладення міждержавних угод про співробітництво у сфері протидії торгівлі людьми).

Підкреслюється важливість віктимологічної профілактики торгівлі людьми. Необхідно працювати з «групою ризику», тобто з особами, які в силу різних життєвих обставин $€$ потенційними жертвами цього злочину, здійснювати індивідуальний вплив на них, надавати їм конкретну допомогу. Відзначається, що своєчасне й точне виявлення тих, хто входить в групу ризику втягнення в торгівлю людьми, $\epsilon$ запорукою успішності запобігання таким злочинам.

Одним із напрямів запобігання торгівлі людьми, вчиненої з метою сексуальної експлуатації, є мінімізація такого суспільного явища як проституція. Підкреслюється, що діяльність правоохоронних органів має бути спрямована передовсім на виявлення осіб, яких примусили до зайняття проституцією, з наступним встановленням винних у такому злочині осіб.

Зроблено висновок про те, що торгівля людьми є складним і багатоаспектним явищем, яке вимагає системного реагування як на загальносоціальному, так і на спеціально-кримінологічному рівні. Підкреслюється перспективність спеціально-кримінологічних заходів запобігання торгівлі людьми, які, за умови належного фінансування та державної підтримки, можуть дати вагомі позитивні результати.

Ключові слова: злочини проти волі, честі та гідності особи, торгівля людьми, спеціально-кримінологічне запобігання злочинам, жертва злочину.

The article analyzes special-criminological measures for the prevention of trafficking in human beings. These measures are classified into information-analytical (systematic collection and analysis of information on the status and tendencies of the relevant

(C) АНДРУШКО А.В. - кандидат юридичних наук, доцент, доцент кафедри кримінального права і процесу (Ужгородський національний університет) 
crimes), educational (informing the population about dangerous situations related to risks of being in the situation of trafficking in human beings, focusing on specific recommendations on how not to become a victim of this crime, public awareness-raising campaigns aimed at changing the attitude towards victims of human trafficking in society, etc.), legal (improvement of the Law of Ukraine "On Combating Trafficking in Human Beings", criminal legislation aimed at counteracting such encroachments, as well as the practice of its enforcement, overcoming the excessive softness of judicial repression in sentencing this crime), organizational and managerial (improving the professional level of law enforcement officials, improving the interaction of law enforcement agencies and civil society institutions, state protection and rehabilitation of victims of trafficking in human beings, etc.), political (activation of efforts aimed at concluding inter-state agreements on cooperation in combating trafficking in human beings).

The importance of victimological prevention of trafficking in human beings is underlined. It is necessary to work with the "risk group", that is, with persons who, due to different life circumstances, are potential victims of this crime, to exercise individual influence on them, to provide them with specific assistance. It is noted that timely and accurate identification of those who are at risk of being involved in trafficking in human beings is a key to successful prevention of such crimes.

One of the ways to prevent trafficking in human beings for the purpose of sexual exploitation is to minimize such a social phenomenon as prostitution. It is emphasized that the activities of law enforcement agencies should be aimed first and foremost at identifying persons who have been forced into prostitution, with the subsequent establishment of perpetrators of such a crime.

It is concluded that trafficking in human beings is a complex and multidimensional phenomenon that requires a systematic response at both the social and special-criminological levels. The article emphasizes the promise of special criminological measures for the prevention of trafficking in human beings, which, if properly funded and supported by the state, can produce significant positive results.

Key words: crimes against freedom, honor and dignity of a person, trafficking in human beings, special-criminological crime prevention, victim of crime.

Вступ. Проблема торгівлі людьми має глибоке соціально-економічне підгрунтя, а тому визначальними мають бути загальносоціальні заходи запобігання цьому явищу. Однак поряд iз заходами загальносоціального запобігання важливе значення мають також заходи спеціально-кримінологічні, які не замінюють, а доповнюють і конкретизують заходи загальної превенції. Заходи спеціально-кримінологічного запобігання торгівлі людьми базуються на заходах загальносоціальних, використовують їх запобіжний потенціал та сприяють йому. На переконання автора, ефективне запобігання розглядуваним діянням можливе за умови поєднання загальносоціальних та спеціально-кримінологічних заходів.

Кримінологічні аспекти торгівлі людьми розглядалися В.С. Батиргареєвою, М.Г. Вербенським, Т.І. Возною, В.В. Голіною, Н.О. Гуторовою, Т.А. Денисовою, Г.П. Жаровською, В.О. Іващенко, К.Б. Левченко, О.В. Лисодєдом, О.В. Наден, А.М. Орлеаном, Ю.В. Раковською, С.Д. Скулишем, Н.В. Сметаніною та іншими науковцями. Водночас доводиться констатувати, що у наявних публікаціях $з$ даної проблематики спеціально-кримінологічним заходам запобігання торгівлі людьми приділялося недостатньо уваги.

Постановка завдання. Мета статті - запропонувати перспективні спеціально-кримінологічні заходи запобігання торгівлі людьми.

Результати дослідження. Заходи спеціально-кримінологічного запобігання торгівлі людьми можна класифікувати на інформаційно-аналітичні (систематичний збір та аналіз інформації про стан і тенденції розглядуваних злочинів), просвітницькі (інформування населення про небезпечні ситуації, пов'язані з ризиком опинитися у ситуації торгівлі людьми, акцентування на конкретних рекомендаціях про те, як не стати жертвою даного злочину, просвітницька діяльність серед населення, спрямована на зміну ставлення до жертв торгівлі людьми у суспільстві, тощо), правові (удосконалення Закону України «Про протидію торгівлі людьми», кримінального законодавства, спрямованого на протидію розглядуваним посяганням, а також практики його застосування, подолання надмірної м'якості судової репресії), організаційно-управлінські (підвищення 
професійного рівня працівників правоохоронних органів, вдосконалення взаємодії правоохоронних органів та інститутів громадянського суспільства, державний захист і реабілітація жертв торгівлі людьми тощо), політичні (активізація діяльності, спрямованої на укладення міждержавних угод про співробітництво у сфері протидії торгівлі людьми).

Торгівля людьми - явище, яке зазнає постійних змін. 3 огляду на це необхідним є постійний збір та аналіз інформації про стан і тенденції торгівлі людьми в Україні. Здійснене автором дослідження засвідчує наявність численних суперечностей, які стосуються кримінологічних даних про цей злочин (йдеться, скажімо, про відмінності між офіційною статистикою і статистикою, яку веде Міжнародна організація з міграції). Зрозуміло, що відсутність об'єктивної інформації стоїть на заваді розробленню конкретних заходів із адекватного реагування на нові виклики. Тому насамперед необхідно володіти об'єктивною інформацією про масштаби та особливості цього явища. Потрібно також знати про кримінологічно значущі відмінності між торгівлею людьми, вчиненою з різною метою експлуатації людини (сексуальною, трудовою тощо), що дозволить диференціювати відповідні заходи запобігання.

Важливе значення має віктимологічна профілактика торгівлі людьми. Необхідно працювати 3 «групою ризику», тобто з особами, які в силу різних життєвих обставин $є$ потенційними жертвами торгівлі людьми, здійснювати індивідуальний вплив на них, надавати їм конкретну допомогу. Точне й своєчасне виявлення тих, хто входить в групу ризику втягнення в торгівлю людьми, є запорукою успішності запобігання таким злочинам.

Необхідно здійснювати масштабне інформування населення про небезпечні ситуації, пов'язані з ризиком опинитися у ситуації торгівлі людьми. Зауважимо, що у науковій літературі висловлювалися критичні міркування стосовно ефективності кампанії з інформування населення про загрозу стати жертвою торгівлі людьми. Так, наприклад, А.М. Орлеан констатує, що «вельми активно розгорнута останнім часом інформаційна кампанія із застереження громадян майже не спроможна вплинути на їх рішення працювати за кордоном». Причиною такого стану речей, на думку науковця, $є$ низький ступінь довіри молоді до 3МІ та державних установ [1, с. 39]. На наш погляд, $€$ й інші причини цього феномену: скрутне матеріальне становище особи, яке штовхає ії на такий крок, попри всі застереження, а також упевненість в тому, що «жертвою експлуатації може стати хто завгодно, але не я». Варто навести також результати проведеного свого часу робочою групою під керівництвом Т.А. Денисової опитування випускниць шкіл ряду українських міст, згідно з яким 49\% опитаних респондентів на запитання про вірогідність стати жертвою сексуальної експлуатації та (чи) використання в порнобізнесі у випадку, якщо їм випаде можливість отримати роботу за кордоном, відповіли, що допускають таку можливість, $6 \%$ бажали б добровільно продати себе в рабство, аби тільки життя було «багатим і ситим» [2, с. 183]. Відзначимо, що наведені результати соціологічного опитування підтверджуються нашим аналізом доступної емпіричної бази. Доводиться констатувати, що молоді жінки нерідко добровільно погоджуються на зайняття проституцією за кордоном, сподіваючись заробити чимало грошей, як їм це обіцяють вербувальники, тобто свідомо роблять такий вибір. Водночас вважаємо, що говорити упевнено про низьку ефективність відповідних інформаційних кампаній достатніх підстав немає, оскільки не існує об'єктивних даних про те, скільки потенційних жертв торгівлі людьми ними все ж не стали саме завдяки таким кампаніям. Тому здійснювати широке інформування населення про загрози стати жертвою торгівлі людьми необхідно й надалі. Важливу роль у цій справі, як відомо, відіграють інститути громадянського суспільства. На наш погляд, варто переглянути окремі підходи до проведення таких кампаній. Як видається, інформування потенційних жертв торгівлі людьми має бути максимально своєчасним і переконливим для тих, хто шукає кращої долі на чужині. Спеціально розроблені пам'ятки, текст яких має містити перелік ознак, за якими можна розпізнати дії торговців людьми, а також контактні телефони для інформування компетентних органів про потрапляння у ситуацію торгівлі людьми, в обов'язковому порядку варто роздавати всім молодим жінкам, які звертаються з метою оформлення закордонного паспорта до Державної міграційної служби чи Центру надання адміністративних послуг, а також при перетині ними державного кордону України.

Здійснений автором контент-аналіз близько 200 публікацій в ЗМІ, присвячених проблемі торгівлі людьми, засвідчує, що абсолютна більшість із них спрямована на інформування населення про виявлені правоохоронними органами факти вчинення даного злочину (при цьому переважно найбільш резонансні). Не заперечуючи доцільності оприлюднення такої інформації, наголосимо на необхідності роз'яснення населенню характерних ознак, за якими можна розпізнати вербувальників та інших торговців людьми, наведення конкретних рекомендацій як не стати 
жертвою торгівлі людьми, а також надання інформації про те, у які організації можна звертатися для отримання юридичної та іншої допомоги. У цьому контексті зауважимо, що Законом України «Про протидію торгівлі людьми» на місцеві державні адміністрації покладений обов'язок забезпечити створення і підтримку «гарячих ліній», пунктів консультування та розповсюдження інформаційно-просвітницьких матеріалів з питань запобігання торгівлі людьми (ст. 8) [3]. Разом 3 тим роботу у цьому напрямі необхідно посилювати, оскільки, як засвідчило проведене нами опитування, відкритої інформації про номери «гарячих ліній» та про місцезнаходження згаданих пунктів консультування дуже бракує.

У суспільстві, як відомо, побутує неоднозначне ставлення до жертв торгівлі людьми. Пов'язано це з тим, що останні, мовляв, погоджувались на роботу чи на зайняття проституцією здебільшого добровільно, знали, що на них чекає, а тому держава не повинна нести відповідальність за тих, хто легковажно й усвідомлено став жертвою цього злочину. Здійснене нами дослідження засвідчило, що багатьох (у тому числі й жертв) дезорієнтує навіть використовувана термінологія, з огляду на яку нерідко робиться висновок, що торгівлі як такої не було (дії, для прикладу, вербувальників іноді сприймаються як цілком «невинні»). Це, своєю чергою, слугує серйозною перешкодою для виявлення фактів торгівлі людьми та успішного розслідування таких злочинів. Окреслений стан речей, вважаємо, необхідно змінювати шляхом здійснення просвітницької діяльності серед населення.

Аналіз емпіричної бази дає підстави для висновку, що жертви торгівлі людьми часто не повідомляють правоохоронні органи про вчинений щодо них злочин, оскільки знаходяться в тій чи іншій залежності від злочинців, бояться фізичної розправи чи розголошення відомостей про рід їхніх занять під час експлуатації, не довіряють правоохоронним органам, хочуть швидше забути пережите тощо. У зв'язку з цим удосконалення потребує система методів виявлення фактів злочинної діяльності, виявлення і звільнення осіб, стосовно яких розглядуваний злочин вже вчинений. Крім того, необхідно вдосконалювати існуючі заходи забезпечення безпеки осіб, які визнані потерпілими від торгівлі людьми, свідків та інших осіб, котрі беруть участь у кримінальному судочинстві у справах щодо торгівлі людьми. Відзначимо, що за оцінками дослідників, чинний на сьогодні Закон України «Про забезпечення безпеки осіб, які беруть участь у кримінальному судочинстві», прийнятий понад двадцять років тому, не повною мірою відповідає викликам сьогодення, а також європейським стандартам та найкращим практикам зарубіжних держав [4].

Необхідно не лише захищати конфіденційні дані вказаних осіб та здійснювати інші заходи із забезпечення їхньої безпеки, а й надавати жертвам торгівлі людьми необхідну допомогу, спрямовану насамперед на їх соціальну реабілітацію, повернення до нормальної життєдіяльності.

Важливим напрямом запобігання торгівлі людьми мають бути правові заходи. Необхідно, зокрема, удосконалювати положення Закону України «Про протидію торгівлю людьми» та інших актів законодавства в частині процедури виявлення і встановлення статусу особи, яка постраждала від торгівлі людьми, прописати належним чином механізм повернення в Україну громадян України, які постраждали від торгівлі людьми, тощо.

Вдосконалення потребують також кримінально-правові засоби протидії торгівлі людьми. Стаття 149 КК України, яка передбачає відповідальність за розглядуване діяння, потребує удосконалення. Серед іншого, необхідно зазначити, що у вересні 2018 р. законодавець безпідставно вилучив «здійснення іншої незаконної угоди, об'єктом якої є людина» 3 переліку тих, які визнаються торгівлею людьми, аргументуючи цей крок необхідністю приведення національного законодавства у відповідність до міжнародних стандартів [5]. Зазначені зміни фактично унеможливили кваліфікацію угод щодо людини, не пов'язаних з її купівлею-продажем (якщо при цьому відсутня мета експлуатації), як торгівлі людьми, що свідчить про наявність серйозної прогалини у кримінальному законодавстві.

Аналіз практики призначення покарання за торгівлю людьми засвідчує надмірний гуманізм вітчизняних судів. Винуватим у вчиненні розглядуваного діяння нерідко призначаються надто м'які покарання. Більше того, переважна більшість засуджених за цей злочин звільняється від відбування покарання з випробуванням. Така практика призводить до того, що засуджена особа не відчуває достатнього карального впливу за вчинене нею діяння, не зазнає адекватного обмеження прав і свобод, що, своєю чергою, не стає належною пересторогою для інших, тих, хто зважується на вчинення даного діяння. У зв'язку з цим автор переконаний, що необхідно забезпечити невідворотність кримінальної відповідальності винних у вчиненні торгівлі людьми, а також адекватність призначуваного покарання вчиненому діянню. 
Серйозного удосконалення потребує методика розслідування торгівлі людьми. Аналіз судової практики засвідчує наявність чималих труднощів, пов'язаних з розслідуванням таких злочинів. Нерідко зібрана у процесі досудового розслідування доказова база грунтується виключно на показах самих потерпілих, а також нечисленних свідків, які до того ж з тих чи інших причин нерідко змінюють свої покази. Це, зрозуміло, призводить до того, що відповідні кримінальні провадження іноді «розвалюються» в суді. У зв'язку з цим необхідно проводити систематичне підвищення кваліфікації працівників правоохоронних органів (передусім співробітників відділів боротьби зі злочинами, пов'язаними з торгівлею людьми). Вважаємо, що серйозну увагу необхідно приділяти не тільки передовим методикам розслідування торгівлі людьми, а й проблемам кваліфікації таких діянь, зокрема питанням розмежування торгівлі людьми та суміжних злочинів.

Запорукою успішного кримінального переслідування винних у вчиненні розглядуваного посягання є належне ставлення співробітників правоохоронних органів до потерпілих від торгівлі людьми. Необхідно виходити з того, що потерпілий від цього діяння $є$ не тільки жертвою, а й, по суті, ключовим свідком, за допомогою якого можна не лише успішно розслідувати цей конкретний злочин, але й, вірогідно, визволити з підневільного стану інших жертв. Тому важливо мотивувати потерпілих до всебічного сприяння правоохоронним органам у розслідуванні торгівлі людьми. Наразі ж, як засвідчує наше дослідження, переважає ситуація, коли потерпілі від вказаного посягання є досить інертними, переймаються здебільшого не покаранням своїх кривдників, а прагненням отримати матеріальне відшкодування.

Удосконалення потребує взаємодія і координація діяльності Національної поліції з іншими правоохоронними органами (зокрема, з Державною прикордонною службою України), інститутами громадянського суспільства. Видається, що особливе значення має налагодження взаємодії правоохоронних органів з громадськими організаціями, завдяки активній діяльності яких проблемі торгівлі людьми в Україні приділяється чимало уваги.

Одним із напрямів запобігання торгівлі людьми, вчиненої з метою сексуальної експлуатації, є мінімізація такого суспільного явища як проституція. Досягти цього результату, зрозуміло, надзвичайно складно. У світі, як відомо, упроваджуються різні практики, спрямовані на мінімізацію проституції - від іiі легалізації до встановлення кримінальної відповідальності за зайняття нею. Не вдаючись у дискусії стосовно доцільності легалізації проституції в Україні, у контексті нашого дослідження зауважимо, що прийняття такого рішення значно обмежить можливості правоохоронних органів щодо доказування ознак складу торгівлі людьми, вчиненої 3 метою сексуальної експлуатації, оскільки вкрай непросто буде довести, що надавати сексуальні послуги жертву примусили. Крім того, легалізація проституції сприятиме зростанню попиту на сексуальні послуги, що, своєю чергою, слугуватиме додатковою мотивацією для активізації відповідної злочинної діяльності з боку зацікавлених осіб ${ }^{1}$. Так само неефективним у розглядуваному контексті видається й встановлення кримінальної відповідальності за зайняття проституцією, оскільки відповідний крок не знизить попиту на сексуальні послуги, а лише сприятиме більшій «тінізації» такої діяльності, а так само й аналізованого незаконного бізнесу. Альтернативним варіантом розв'язання проблеми є досвід Швеції, законодавство якої передбачає кримінальну відповідальність не за зайняття проституцією, а за користування відповідними послугами. Водночас, на наш погляд, і такий крок не буде ефективним заходом спеціально-кримінологічного запобігання торгівлі людьми з метою сексуальної експлуатації, позаяк також сприятиме «тінізації» такої діяльності. Крім того, варто мати на увазі, що сексуальна експлуатація жертв розглядуваного злочину, як правило, відбувається за кордоном, а тому встановлення в КК України відповідальності для клієнтів секс-послуг ефективним заходом запобігання торгівлі людьми не буде. Як видається, діяльність правоохоронних органів має бути спрямована передовсім на виявлення осіб, яких примусили до зайняття проституцією, з наступним встановленням винних у такому злочині осіб. Необхідно також надавати всебічну допомогу тим жінкам, які виявили бажання порвати з цим видом діяльності, здійснювати статеве виховання підростаючого покоління, здійснювати ранню профілактику відхилень у сфері сексуальних стосунків тощо. На жаль, доводиться констатувати, що профілактиці проституції в Україні приділяється мало уваги. У зв’язку з цим

1 Зауважимо, що з цього приводу існує й інша точка зору. На думку окремих дослідників, легалізація проституції допоможе покінчити з експлуатацією незаконно ввезених в країну жінок-іммігранток і в якості позитивного прикладу наводиться досвід Нідерландів. Водночас необхідно зазначити, що абсолютна більшість повій у голландських борделях походить 3 інших країн, частина 3 них - жертви торгівлі людьми [див.: 6, с. 255]. 
варто погодитись з О.М. Джужею, який наголошує на необхідності розроблення загальнодержавної програми боротьби з проституцією [7, с. 187].

Важливе значення має робота, спрямована на виявлення та припинення діяльності різноманітних закладів, котрі, прикриваючись туристичною, рекрутинговою чи іншою подібною діяльністю, фактично є центрами з організації нелегальної трудової міграції, постачальниками українських жінок на міжнародні ринки сексуальних послуг. Необхідним також є постійний моніторинг інтернет-ресурсів, на яких здійснюється вербування потенційних жертв розглядуваного злочину.

Потрібно поліпшувати прикордонний контроль, удосконалювати контроль паспортів та інших документів, які дають право виїзду з України та в’їзду в Україну. У цьому контексті варто зазначити, що Протокол про попередження і припинення торгівлі людьми, особливо жінками і дітьми, і покарання за неї, що доповнює Конвенцію ООН проти транснаціональної організованої злочинності, вимагає від держав учасниць, однією з яких є Україна, вживати заходи у сфері обміну інформацією і підготовки кадрів з питань попередження торгівлі людьми, а також заходи, спрямовані на захищення та надійність подорожніх документів або посвідчень особи (ст. ст. 10-13) [8]. Зауважимо, що здійснений аналіз емпіричної бази засвідчив: в ряді випадків саме завдяки пильності прикордонників, які звернули увагу на «проблемні» документи, вдалося завадити переміщенню завербованих осіб через державний кордон України.

3 огляду на те, що торгівля людьми здебільшого є транснаціональним злочином, вирішити дану проблему на рівні однієї держави неможливо. Здійснений автором аналіз судової практики засвідчує, що до кримінальної відповідальності за розглядуваний злочин притягаються майже винятково ті, хто діяв на території України, тоді як їхні співучасники, котрі діяли на території інших держав, як правило, залишаються непокараними. 3 огляду на це вкрай необхідно активізувати діяльність, спрямовану на укладення міждержавних угод про співробітництво у сфері протидії торгівлі людьми, а також встановлення прямих зв'язків з правоохоронними органами інших держав. Це дозволить вирішити численні труднощі, пов'язані з розслідуванням фактів торгівлі людьми, сприятиме притягненню до відповідальності іноземців, причетних до організованих злочинних угруповань, що займаються такою діяльністю [9, с. 135]. Підкреслимо, що удосконалення інформаційного обміну і професійної взаємодії важливе з правоохоронними органами передовсім тих держав, котрі входять до числа найвідоміших країн призначення «живого товару».

Висновки. Торгівля людьми є складним і багатоаспектним явищем, яке вимагає системного реагування як на загальносоціальному, так і на спеціально-кримінологічному рівні. Є підстави для висновку про те, що система заходів спеціального запобігання торгівлі людьми перебуває на стадії свого становлення. Видається, що на цьому напрямку існує величезний простір для роботи, яка, за умови належного фінансування та державної підтримки, може дати вагомі позитивні результати.

\section{Список використаних джерел:}

1. Орлеан А.М. Кримінально-правова характеристика торгівлі людьми. Монографія. Харків : CIM, 2005. 180 c.

2. Денисова Т.А. Торговля женщинами и детьми с целью их сексуальной эксплуатации: исследования в Украине. Злочини проти особистої волі людини: збірник матеріалів науково-практичного семінару (Харків, 19-20 вересня 2000 р.) / під ред. В.В. Сташиса. Харків : Книжкове видавництво «Лествиця Марії», 2002. С. 179-184.

3. Закон України «Про протидію торгівлі людьми» від 20 вересня 2011 р. № 3739-VI. URL: https://zakon.rada.gov.ua/laws/show/3739-17.

4. Семків Т. Удосконалення забезпечення безпеки осіб, які беруть участь у кримінальному провадженні. Науковий часопис Національної академії прокуратури Украӥни. 2017. № 3. C. 119-128.

5. Пояснювальна записка до проекту Закону України «Про внесення змін до статті 149 Кримінального кодексу України (щодо приведення у відповідність до міжнародних стандартів)». URL: http://w1.c1.rada.gov.ua/pls/zweb2/webproc4_1?pf3511=61428

6. Назаренко Д.О. Протидія проституції як фоновому для злочинності явищу. Наукові записки Львівського університету бізнесу та права. 2013. Вип. 11. С. 254-258.

7. Джужа О.М. Запобігання злочинам, пов'язаним із сексуальним насильством: монографія. Київ : Атіка, 2009. 240 с.

8. Протокол про попередження і припинення торгівлі людьми, особливо жінками і дітьми, і покарання за неї, що доповнює Конвенцію ООН проти транснаціональної організованої 
злочинності, прийнятий резолюцією 55/25 Генеральної Асамблеї від 15 листопада 2000 p. URL: https://zakon.rada.gov.ua/laws/show/995_791

9. Андрушко А.В., Нестерова І.А. Злочинність у сфері туристичного бізнесу: кримінологічна характеристика та запобігання: монографія. Ужгород : ТОВ «IBA», 2016. 220 с.

УДК 343.9

DOI https://doi.org/10.32844/2618-1258.2019.5-1.38

БАРДАЧОВ В.В.

\section{ЗЛОЧИНИ У СФЕРІ СЛУЖБОВОЇ ДІЯЛЬНОСТІ, ЯКІ ВЧИНЯЮТЬ ПРАЦІВНИКИ ПАТРУЛЬНОЇ ПОЛЦІЇ, ЯК ОБ'ЄКТ КРИМІНОЛОГІЧНОГО ДОСЛІДЖЕННЯ}

У статті надано кримінально-правову характеристику злочинам у сфері службової діяльності, що вчиняють працівники патрульної поліції. Встановлено, що до службових та корупційних правопорушень належать діяння, за які передбачено кримінальну, адміністративну, цивільно-правову та дисциплінарну відповідальність та які розподілено на такі, що пов'язані з виконанням працівниками Національної поліції службових обов'язків (службові зловживання), використанням ними спеціального правового статусу для вчинення інших злочинів, а також, які учинено поза службою.

Злочини у сфері службової діяльності, що вчиняються працівниками патрульної поліції - це суспільно небезпечні протиправні діяння, передбачені розділом XVII Особливої частини закону про кримінальну відповідальність, що посягають на нормальну діяльність правоохоронних органів та вчиняються громадянами України, які склали Присягу поліцейського, проходять службу на відповідних посадах у патрульній поліції і яким присвоєно спеціальне звання поліції під час виконання ними службових обов'язків. Зазначені суспільно небезпечні діяння поділяються на ті, що пов'язані із загально-професійними аспектами діяльності (ст. 364, 365,367 КК України), ті, що пов'язані із набуттям або укриттям незаконної матеріальної вигоди (366-1, 368, 369, 369-2 КК України), та ті, що пов'язані із спеціальною діяльністю (ст. 366, 370 КК України). Залежно від категорії посади (служби, підрозділу) змінюється специфіка виконуваних службових функцій, а отже, і зміст службових повноважень та компетенції, якими працівники володіють відповідно до службового становища. Водночас використання службових повноважень і можливостей, що передбачені службовим становищем, крім того, буде зумовлювати не тільки різний характер злочину, але і тяжкість наслідків.

Злочини у сфері службової діяльності, що вчиняються працівниками патрульної поліції, $є$ сегментом корупційних правопорушень, учинених працівниками правоохоронних органів. Серед чинників, що сприяють поширенню таких діянь у поліції та їх латентності, головними варто визнати недостатньо чітку регламентацію службових повноважень груп кадрів і категорій персоналу, приховування слідів як самими правопорушниками, так і їх безпосередніми керівниками, а також зв'язок службових зловживань з іншими категоріями правопорушень, до яких можуть бути причетні потерпілі та інші зацікавлені особи. Забезпечення належного стану дисципліни та законності серед особового складу поліції грунтується на стратегії випередження, що полягає у проведенні комплексу заходів, спрямованих на виявлення, запобігання й припинення корупційних, злочинних та інших протиправних діянь у поліцейських колективах.

Ключові слова: кримінально-правова характеристика, кримінальне правопорушення, злочин, корупція, патрульна поліція.

(С БАРДАЧОВ В.В. - здобувач кафедри кримінально-правових дисциплін та судових експертиз (Донецький юридичний інститут Міністерства внутрішніх справ України) 